\title{
Factor affecting public acceptance on Genetically Modified Food: A Review
}

\author{
Anastasia Aliesa Hermosaningtyas \\ Institute of Biology Molecular and Biotechnology, Faculty of Biology, Adam Mickiewicz University, Poznań, \\ 61614, Wielkopolskie, Poland \\ *Corresponding author: anaher@st.amu.
}

\section{ABSTRACT}

Food security is becoming one of the problematic concerns due to world population expansion, estimated to reach 10 billion people by 2050. Despite the benefits of GM foods and their application, there are still concerns and rejections from society. Public knowledge of GM technology and GM products remains the main factor towards general attitude and acceptance, followed by socioeconomic factors, trust in public authorities and regulations, media, and communication.

Keywords: Genetically Modified Food, food security, consumer acceptance, risk and benefit perception

\section{INTRODUCTION}

The latest data from the United Nations Department of Economic and Social Affairs stated that the global population reached 7.7 billion by mid-2019. Even though the growth rate of the world's population is slowing down to $1.1 \%$ per year, it is expected to reach almost 10 billion people by 2050 (1). Challenges arise from world population expansion. One of the problematic concerns is securing food security.

FAO defines food security as a situation when members of the society always have physical, social, and economic access to sufficient, safe, and nutritious food. These foods must meet the dietary needs and preferences for an active and healthy life. According to FAO's report in 2020, $108 \mathrm{M}$ people in 48 countries were in Crisis (huge consumption gaps and malnourish) or worser conditions in 2016. This number increased to $124 \mathrm{M}, 113 \mathrm{M}$, and $135 \mathrm{M}$ people in \pm 50 countries in 2017,2018 , and 2019, respectively (2). Studies have predicted that we need to increase food production up to $70 \%$ before 2050 to eradicate this problem (3).
Genetically modified (GM) foods have been offered as a solution to ensure food security. Newer developments of GM foods add additional benefits of providing environmental protection and sustainability, aside from increasing food production. Despite those benefits, there are still concerns and rejections from society. Why is this polarization of opinions and believes happening? What factors have caused it? This review will summarize possible factors affecting public acceptance of GM foods.

\section{METHODS}

This paper is an integrative review of selected articles published in the last 16 years (20052021) and focuses on commercially available genetically modified food (GMO).

\section{RESULT AND DISCUSSION}

\section{Genetically Modified Organism}

The World Health Organization (WHO) defines GM foods as foods derived from 
organisms with direct modification to their genetic material (DNA) by introducing a gene from a different organism. The genetic engineering technique to produce GM plants differs from conventional breeding. The differences occur not only in the method of introduction but also in the result/yield obtained from the offspring.

Conventional plant breeding relies on cross- and self-pollination strategies, which means offspring plants contain a random combination of parental genetic materials. The best offspring with traits are selected after a systemic selection, which consumes a lot of (4). On the other hand, GM plants are not designed to develop a new variety, rather a genetically modified trait. GM technology complements conventional plant breeding by introducing the trait of interest to the already adapted varieties from conventional plant breeding. A side benefit from GM technology is conserving varietal diversity (5). This genetic modification technique is also applicable to GM animals with the intention of consumption or drug production.

It has been almost three decades since the first commercial GM food in the market, the tomato FLAVR SAVR ${ }^{\mathrm{TM}}$ in 1994. Since then, GM technology applications for food have grown and spread rapidly in the world. Based on ISAAA brief report 2018, 2.34 million hectares of biotechnology produce (soybean, maize, cotton, and canola) have been grown commercially. Currently, 26 countries are planting GM crops, in which 21 countries are developing countries: Brazil (27\%), Argentina (23.9\%), India (6\%), China (2.8\%), Paraguay (2\%), Pakistan (1\%), South Africa (1\%), Uruguay (1\%), Bolivia, Philippines, Myanmar, Sudan, Mexico, Colombia, Vietnam, Honduras, Chile, Bangladesh, Costa Rica, Indonesia, and eSwatini. The remaining five industrialized countries are the United States of America (USA), Canada, Australia, Spain, and Portugal $(6,7)$. The USA is also the first country to approve releasing a transgenic animal, AquAdvantage Salmon, to the US market in 2015 (8). The most recent approval by FDA is the GalSafe Pig for human consumption and human therapeutics production in 2020 (9). General public acceptance in various countries
Multiple studies indicate that public perception and acceptance of GM food varies among nations. As mentioned before, several developing countries embrace GM technology application in their food. Positive attitudes by people in developing countries are stimulated by the scarcity of food quantity and quality.

Therefore, more people are willing to buy GM foods (10). In the African continent, a new wave of GM food acceptance is evolving. Kenya, South Africa, and Egypt have gradually embraced GM technology and products, followed by Nigeria, Ghana, Burkina Faso, and Ethiopia (11). US customers and farmers are also showing a positive attitude towards GM products. Permissive regulations released by FDA for GM products is helping GM plants and food and feed penetrate the US market (6) rapidly.

In contrast, European countries are very stringent for GM food approval and regulation, except for Spain and Portugal. Strict policies for GM cultivation or import of GM foods and feeds cause a long delay for GM crops authorization in EU countries. The EU also has been imposing labelling regulations for GM food and feed products since 1992. Media and environmental NGOs have often expressed their resistance against GM foods. Therefore, there are increasing negative perceptions towards GM food from EU customers (6).

\section{Knowledge}

Knowledge is an important factor in consumer decision-making and information processing activities. Several findings indicate that the depth of customer knowledge on GM technologies and GM products is highly related to customer perception of the risk and benefit of GM foods $(6,10,12-17)$. Risk and benefit perception is a subjective judgment on the characteristic and potential hazard. It has been identified as being more crucial in personal acceptance of GM foods compared to technical risk assessments made by researchers. Customers with more advanced knowledge can analyze risk and benefits rationally. These customers tend to accept GM technology and its application on food products. Customers with insufficient knowledge perceive GM food negatively because they are uncertain about the 
risk and benefits of GM foods. This group of customers is more susceptible to external sources (mass media) that depict negative images and risk communication towards GM foods (6).

Discussions on the correlation between knowledge and customer acceptance have differentiated between subjective knowledge and objective knowledge (18) or perceived familiarity and factual knowledge (17). Objective or factual knowledge measures the amount of genuine information (from textbooks) the individuals have about the concept. Perceived familiarity/subjective knowledge is a self-reported measurement of how well informed the individuals believe themselves to be about the concept. Understanding the impact of each knowledge helps researchers and regulation makers to learn how it affects customers' decisions on risk and benefit perception. Researches by Liu et al. and Rose et al. have yielded interesting results. Objective knowledge is the determining factor of consumers' attitudes, with the grade of objective knowledge dependent on values. Consumers' subjective knowledge/perceived familiarity do not have a significant impact on risk and benefit perceptions. Subjective knowledge could be capturing the effect of selective exposure in which respondents are more familiar with and match the respondents' personal beliefs. These findings support the idea that promotion of GM foods in logic- and scientific-based methods with a focus on benefits communication could change customers' perspective on GM foods.

\section{Trust in public authorities, media, and communication}

Studies in several countries show that customers tend to trust policies released by the authorities regarding GM technology and its application. A study in Norway aimed to assess the public's acceptance of GM food, GM-fed animals, and GM-livestock shows that trust in food authorities reduces GM aversion (16). Hu et al. pointed out the importance of epistemic trust on preceding risk and benefit perception and how it indirectly affects public acceptance of GM food in China. Their data also supports the hypothesis that customers positively perceive
GM foods by trusting the authorities (19). The latest study conducted in Japan also indicates that Japanese customers tend to trust information and regulations administrated by their government and positively accept GM technology and GM foods (13).

Strict policies in several European countries regarding the application of GM technology in several countries have given the impression that GM foods are unsafe and concerning. The European Union imposes strict regulations on GM cultivation, import regulations for GM products, and labelling rules for GM products. These policies have made customers in the EU more sceptical and have lower intention to purchase any GM foods (14).

The effectiveness of GM-related campaigns by the authorities and/or media depends on written and visual communication techniques. Pham and Mandel in their publication emphasize that selection of the words used in messages/commercials could either alter or intensify the attitude of customers towards GM food products. In messages focusing on safety and benefits, positive responses were given by the pro-GM customer and weak anti-GM customer. On the other hand, anti-GM customers give these messages a strong negative response and perceive them as a risk message. This leads to the suggestion of using a benefit message to promote GM foods, as it leads to more positive attitudes and reduces risk perception from customers (20). Farid et al. suggested utilizing more scientific communication to enhance customers' trust, acceptance, and willingness to pay GM foods, especially young customers $(13,17)$. Nevertheless, it is prudent to mention that science-based communication messages should not be used to persuade customers but more as a way to spread information on the risks and benefits of GM foods that could lead to acceptance. Done correctly, effective scientific communication can achieve this goal (21).

Visual messages also contribute to public acceptance of GM foods. Communication messages with visual aids are supported by the 'superiority effect' theory, in which visual images are easier to remember than complex words and long explanations. Therefore, it can fulfil the blank area of knowledge on GMrelated topics $(14,22)$. Ventura et al. also 
suggested that visual communication could raise emotions (fear, hope, guilt, compassion, and nostalgia); said emotions can play a role in solidifying the risk. Based on their observation, online media visuals that depict GM foods in unrealistic and scary tones have garnered more views. These images use 'unnatural' as the key theme and contribute to inducing negative customer perception by adding the element of fear.

\section{CONCLUSION}

Genetically modified food is a valuable option for resolving current and future problems in ensuring food security worldwide. It has been proven to improve food production and ensure food availability, improving human resources and socio-economy aspects in nations embracing GM foods. Despite this, there are still concerns and rejections from society. Several factors affecting public acceptance of GM foods are knowledge, public trust in authorities and regulations released for GM foods, media exposure, and tone of communications.

Knowledge is an important factor in consumer decision-making and information processing activities and is highly related to customer perception of the risk and benefit of GM foods. In general, customers with advanced knowledge obtained the ability to analyze risks and benefits rationally. The public tends to trust policies released by the authorities regarding GM technology and its application. Public from countries with permissive regulations is shown to be more accepting of GM foods. Mass media often use unreal and scary images to picture GM products and focus on risk communication. Unfortunately, these impressions might easily affect the public with insufficient knowledge. Benefit communication based on logic and a scientific approach could be the best way to alter the public's negative perspective on GM foods.

\section{ACKNOWLEDGMENT}

We thank you Prof. Tomasz Twardowski and dr. Laurensia Vidya for all support and insights on this writing.

\section{REFERENCES}

[1] Knoema. World population prospects 2019 [Internet]. Department of Economic and Social Affairs. World Population Prospects 2019. 2019. 1-39 p. Available from:

http://www.ncbi.nlm.nih.gov/pubmed/122 83219

[2] FSIN. GLOBAL REPORT ON FOOD CRISES: Acute food insecurity and malnutrition forecasts for 2020. Food Secur Inf Netw [Internet]. 2020;1-202. Available from: https://www.wfp.org/publications/2020global-report-food-crises

[3] Mc Carthy U, Uysal I, Badia-Melis R, Mercier S, O’Donnell C, Ktenioudaki A. Global food security - Issues, challenges and technological solutions. Trends Food Sci Technol [Internet]. 2018;77(August 2017):11-20. Available from: https://doi.org/10.1016/j.tifs.2018.05.002

[4] Shan-e-Ali Zaidi S, Vanderschuren H, Qaim M, Mahfouz MM, Kohli A, Mansoor S, et al. New plant breeding technologies for food security. Science (80- ). 2019;363(6434):1390-1.

[5] Qaim M. Genetically Modified Crops and Agricultural Development. Hampshire: Palgrave Macmillan; 2016.

[6] Lucht JM. Public acceptance of plant biotechnology and GM crops. Viruses. 2015;7(8):4254-81.

[7] ISAAA. Global Status of Commercialized Biotech/GM Crops in 2018: Biotech Crops Continue to Help Meet the Challenges of Increased Population and Climate Change. ISAAA Brief No. 54. ISAAA $\mathrm{Br}$ No 54 ISAAA Ithaca, NY [Internet]. 2018;21. Available from: http://www.isaaa.org/resources/publicatio ns/briefs/54/executivesummary/pdf/B54ExecSum-English.pdf

[8] FDA. AquAdvantage ${ }^{\circledR}$ Salmon Environmental Assesment. 2018;

[9] FDA. GalSafe ${ }^{\circledR}$ Pigs - Environmental Assessment. 2020;

[10] Al-Khayri JM, Hassan MI. Sociodemographic factors influencing public 
perception of genetically modified food in Saudi Arabia. Am J Food Technol. 2012;7(3):101-12.

[11] Animasaun DA, Azeez MA, Adubi AO, Durodola FA, Morakinyo JA. Trends in genetically modified crops development in Nigeria: issues and challenges. 1st ed. Andersen V, editor. Genetically Modified and Irradiated Food: Controversial Issues: Facts versus Perceptions. London: Elsevier Inc.; 2020. 1-298 p.

[12] Moerbeek H, Casimir G. Gender differences in consumers' acceptance of genetically modified foods. Int $\mathbf{J}$ Consum Stud. 2005;29(4):308-18.

[13] Farid M, Cao J, Lim Y, Arato T, Kodama K. Exploring factors affecting the acceptance of genetically edited food among youth in Japan. Int $\mathbf{J}$ Environ Res Public Health. 2020;17(8).

[14] Frewer LJ. Consumer acceptance and rejection of emerging agrifood technologies and their applications. Eur Rev Agric Econ. 2017;44(4):683-704.

[15] Elder L, Greene S, Lizotte MK. The gender gap on public opinion towards genetically modified foods. Soc Sci J [Internet]. 2018;55(4):500-9. Available from:

https://doi.org/10.1016/j.soscij.2018.02.01 5

[16] Ardebili AT, Rickertsen K. Personality traits, knowledge, and consumer acceptance of genetically modified plant and animal products. Food Qual Prefer [Internet]. 2020;80(October 2019):103825. Available from: https://doi.org/10.1016/j.foodqual.2019.10 3825

[17] Rose KM, Howell EL, Su LYF, Xenos MA, Brossard D, Scheufele DA.
Distinguishing scientific knowledge: The impact of different measures of knowledge on genetically modified food attitudes. Public Underst Sci. 2019;28(4):449-67.

[18] Liu G, Zhang M. The effects of customer's subjective and objective knowledge on perceptions and attitude towards genetically modified foods: objective knowledge as a determinant. Int J Food Sci Technol. 2015;50:1198-205.

[19] $\mathrm{Hu}$ L, Liu R, Zhang W, Zhang T. The effects of epistemic trust and social trust on public acceptance of genetically modified food: An empirical study from China. Int J Environ Res Public Health. 2020;17(20):1-21.

[20] Pham N, Mandel N. What Influences Consumer Evaluation of Genetically Modified Foods? J Public Policy Mark [Internet]. 2019;38(2):263-79. Available from: https://doi.org/10.1177/074391561881816 8

[21] Harfouche AL, Petousi V, Meilan R, Sweet J, Twardowski T, Altman A. Promoting Ethically Responsible Use of Agricultural Biotechnology. Trends Plant Sci [Internet]. 2021;1-14. Available from: https://doi.org/10.1016/j.tplants.2020.12.0 15

[22] Ventura V, Frisio DG, Ferrazzi G, Siletti E. How scary! An analysis of visual communication concerning genetically modified organisms in Italy. Public Underst Sci. 2017;26(5):547-63. 